\title{
Carga argumentativa em decisões vinculantes do Supremo Tribunal Federal
}

\author{
Burden argumentative in Supreme \\ Court binding opinion
}

Rogério José Bento Soares do Nascimento ${ }^{1}$

\section{RESUMO}

O trabalho discute o dever de fundamentação das decisões proferidas no controle concentrado e abstrato de constitucionalidade por parte da jurisdição constitucional brasileira. Apoiado na ética do discurso e na teoria da argumentação, sustenta a necessidade de satisfazer a um ônus argumentativo mais forte para legitimar a autoridade dos julgados.

\section{PALAVRAS-CHAVE}

Jurisdição constitucional; legitimidade; argumentação.

\section{ABSTRACT}

This paper discusses the duty to state reasons for decisions made in concentrated and abstract control of constitutionality by the Brazilian constitutional jurisdiction. Based on the ethics of discourse and argumentation theory, this paper holds the need to satisfy a stronger argumentative burden to legitimize the authority of the courts.

\section{KEYWORDS}

Constitucional jurisdiction; legitimacy; argumentation.

\section{APRESENTAÇÃO}

A reflexão aqui desenvolvida traz como propósito discutir aspecto da legitimação das decisões adotadas com efeito vinculante pelo Supremo Tribunal Federal quando investido da sua função primordial de defesa da integridade do pacto constituinte, mais exatamente, o estilo argumentativo. Há, subjacente na exposição a premissa segundo a qual todo o sistema de Direitos tem de ser compreendido a partir de um projeto de integração que, no Brasil, tem como chave o princípio democrático. Um sistema

1 Pós-Doutorado pela Universidade Federal do Paraná. Doutor em Direito pela Universidade do Estado do Rio de Janeiro - 2003. Mestre em Direito pela Pontifícia Universidade Católica do Rio de Janeiro. 
democrático depende da garantia de participação influente do povo na condução do próprio destino, inclusive no que toca a delimitação dos sentidos que podem ser extraídos do compromisso constitucional, o qual, serve de fundamento e de moldura para a coexistência, penetrando todos os campos da vida comum.

Há implícito na abordagem do tema da legitimação argumentativa a convicção de que a realidade constitucional tem levado ao reforço do papel do Poder Judiciário como um todo, e da jurisdição constitucional em particular, na tessitura dos vínculos que podem promover ou comprometer o convívio social. Um convívio que, nos marcos de um Estado Constitucional de Direito se aspira seja uma empreitada duradoura; bem como a convicção de que este poder jurisdicional, que se agiganta neste começo de século, como todo poder democrático, também precisa ser controlável e consentido.

Antes de prosseguir vale fazer um esclarecimento de método. A abordagem do tema traz implícita uma atitude de otimismo científico (crença na virtude da razão metódica) e opção por um sincretismo metodológico justificado por um projeto de antropofagia epistemológica. Refuta-se todo tipo de ceticismo e relativismo, que se tem por paralisantes, ao mesmo tempo em que se supõe, diante do contexto heterogêneo e desigual, ocidental e periférico brasileiro, não haver lugar para ortodoxia de métodos. É frutífero e tem mais alcance prático a opção de absorver toda contribuição de pensamento, mesmo aquele produzido em diferente contexto, no propósito de formar e enriquecer um pensamento próprio. Isso não significa, entretanto, deixar de se inserir em uma tradição nítida na medida em que há uma adesão explícita à ética do discurso, pelo viés habermasiano, como marco que se acredita útil para orientar a crítica de sociedades abertas e complexas sob compromisso de emancipação pela via democrática.

\section{A IMPORTÂNCIA DA LINGUAGEM NA MOTIVAÇÃO DAS DECISÕES}

Chega a ser corriqueiro invocar a mitologia grega e romana na demonstração de traços da cultura americana. No campo do direito e em particular da interpretação a figura de Hermes é destacada ${ }^{2}$. Mitos, fora da sua função de orientar preceitos e ritos religiosos, são narrativas compartilhadas que moldam identidades. Suponho que, dado que existimos mesmo onde não pensamos, e que a atuação do direito se dá para e por sujeitos capazes de fazer escolhas e de formular representações sobre a realidade na qual estão inseridos, não está ao nosso alcance dispensar mitos. Penso que é preciso fundar uma mitologia democrática. E talvez não estejamos capacitados a discernir entre mitos mais ou menos adequados sem uma filosofia da consciência, mas este seria tema para outro artigo.

De se ver que na tradição ocidental o direito é alçado ao status de doutrina coerente erguendo-se sobre fontes gregas e latinas. Nesta origem há um grande peso para a retórica, a arte da palavra tomada como reação anti-sofista, um discurso ordenado com técnica e com ética ${ }^{3}$, um peso que a principiologia do nosso tempo obrigou resgatar. A ars jurídica e a scientia iuris, o ius redigere in artem, envolve a busca do justo e do igual (ars bona et aequi), passa por descobrir uma justiça (na esfera pública se aspira justiça na esfera privada se aspira honestidade) que exprime o certo - de(di) rectum. Com tal missão a

${ }^{2}$ Cf. STRECK, Lênio. Apresentação a obra Hermenêutica Constitucional de TRIBE, Laurence e DORF, Michael. Belo Horizonte, Del Rey, 2007. pág. xii-xv.

${ }^{3}$ Aristóteles se ocupa detalhadamente da retórica judicial (ou forense), um dentre os três gêneros de retórica que enumera, ao lado da deliberativa (ou política) e da epidíctica (ou demonstrativa), apontando-a como aquela que se ocupa da injustiça e suas causas. Retórica. Lisboa, Imprensa Nacional-Casa da Moeda, 2006, p. 130-155. 
jurisprudência supõe e exige do jurista o conhecimento das coisas humanas e divinas constans et perpetua voluntas jus suum cuique tribuendi. ${ }^{4} \mathrm{Um}$ acesso que é mediado e pode ser facilitado ou dificultado dependendo do uso que é feito da linguagem. O jurista e a Corte têm de cavere, cuidar, antecipar consequências e prevenir o mal, de agere, promovendo, acionando e sendo acionado com argumentos e em busca de persuadir, e respondere, julgar com autoridade, sabendo que a resposta incorpora e traz com ela a dialética e a retórica do agir argumentativo que a prepara e possibilita.

\section{EFEITO VINCULANTE NAS DECISÕES DO SUPREMO TRIBUNAL FEDERAL}

A atribuição do papel de Corte Constitucional ao Supremo Tribunal Federal foi natural. A herança jurídica portuguesa nos legou tanto um modelo de direito apoiado na legalidade quanto um aparato jurisdicional já institucionalizado. Nos legou também uma cultura burocrático-autoritária. $\mathrm{O}$ poder régio, que se consolidou com a expansão territorial ultramarina, reclamou e criou condições para instituições centralizadoras do período Filipino (como o Conselho das Índias de 1604, que sofre um breve hiato com a União Ibérica). Com a restauração do estado, em 1640, o movimento centralizador veio a ser retomado e o antigo Conselho das Índias se transforma em Conselho Ultramarino em 1642. Esse movimento foi ampliado sob a regência e o reinado de D. Pedro II (1667 a 1706) e teve o seu auge no reinado de D. José I, sob liderança do Marques de Pombal (1750 a 1777). Vigorou um absolutismo ilustrado e modernizante que inicia a redução dos poderes nobiliárquicos e a secularização (por exemplo, expulsando os jesuítas), esse modelo se faz sentir na América portuguesa com a estruturação do poder judicial, primeiro, com a criação e instalação da Relação de Salvador, depois, com a criação da Relação do Rio de Janeiro, culminando com a transferência da família real em 1808. Fomos território com administração e burocracia antes de termos povo e independência.

A necessidade de defesa da República nascente, que diferentemente do Império era, ao menos no plano simbólico, fruto imediato e exclusivo da soberania popular, conjugada com a influência Norte-americana e com a opção por rigidez constitucional já conduziria naturalmente para alguma forma de controle de constitucionalidade (CARVALHO, 2007) $)^{5}$. O tempo e os sucessivos pactos político-constitucionais foram apenas delineando o nosso modelo peculiar de jurisdição constitucional.

O modelo misto representa uma conciliação do sistema de fontes centrado na legalidade, no direito escrito, no qual as decisões judiciais são aplicadoras de normas com validade restrita às partes com um sistema de valorização da jurisprudência produtora de decisões com força de lei. O direito escrito que constitui um obstáculo para a interpretação criadora do juiz pode ser superado no exame de constitucionalidade frequentemente

\footnotetext{
4 CUNHA, Paulo Ferreira da. Retórica e Hermenêutica na origem do direito. Disponível em: <http://www.hottopos.com/videtur17/pfc_retdir.htm>. Acesso em: 20 mai. 2016.

5 "Havia pelo menos três modelos à disposição dos republicanos brasileiros. Dois deles, o americano e o positivista, embora partindo de premissas totalmente distintas, acabavam dando ênfase ao aspecto da organização do poder. 0 terceiro [jacobino] colocava a intervenção popular com fundamento do novo regime, desdenhando os aspectos de institucionalização". CARVALHO, José Murilo. A formação das Almas. O imaginário da República no Brasil. Rio de Janeiro, Cia das Letras, $17^{a}$ reimpressão, 2007, p. 22. Benjamim Constant expressa o projeto positivista, Silva Jardim o jacobino e Rui Barbosa a influência Norte-americana fortemente refletida no texto da Constituição de 1891.
} 
apoiado em uma argumentação por princípios usados para superar limites textuais ou para corrigir o "anacronismo legislativo" (cessant ratione legis, cessat ipsa lex).

Uma vez introduzido o controle concentrado de constitucionalidade com a Emenda Constitucional no 16/1965, já sob o regime militar instaurado em 1964, depois que o governo assegurou sua influência sobre o STF ampliando com o Ato Institucional 2 o número de integrantes de 11 para $16 \operatorname{membros}^{6}$, a vinculação por precedente era uma decorrência natural. Com o alargamento dos interesses constitucionalmente protegidos, o reforço da necessidade de proteção do pluralismo político e social, enriquecendo o sentido de democracia e o estabelecimento de um consenso teórico a respeito da força normativa de todas as disposições constitucionais, inclusive as normas de princípio o exercício da jurisdição constitucional assumiu um papel político destacado. Não há, na atualidade, tema relevante da convivência social que não esteja refletido nas modernas constituições e por isso, nada escapa de exame pela Jurisdição Constitucional.

Com a recuperação da legitimidade constitucional em 1988 houve a ampliação do rol dos legitimados para provocar o exame da constitucionalidade pela via principal concentrada e em abstrato, abrindo espaço para minorias políticas por meio dos partidos políticos representados no Congresso Nacional (CF, art. 103, VIII) e da adoção de um modelo extrovertido que contempla atores da sociedade civil (CF, art. 103, IX). Além do mais o repertório de meios para controle da conformidade constitucional foi ampliado, originalmente, com a Ação de Inconstitucionalidade por Omissão (CF, art. 103, § $2^{\circ}$ ) e, na revisão de 1993, com a Ação Direta de Constitucionalidade (CF, art. 102, I, letra "a", segunda parte). Foi também preservada a ação interventiva (CF, art. 36, II), concentrada, mas incidental, e introduzida a Arguição de Descumprimento de Preceito Fundamental $\left(\mathrm{CF}\right.$, art. 102, $\left.\S 2^{\circ}\right)$, veículo esse que só se firmou como alternativa viável de exercício de jurisdição constitucional com a Lei no 9.882/99 (BARROSO, 2009, pág. 259). A objetivação do modelo brasileiro teve início com a breve Constituição de 1934 que introduziu a competência do Senado para suspender a execução de normas declaradas inconstitucionais pelo STF (CF, art. 91, IV $)^{7}$ e a reserva de plenário $\left(\mathrm{CF}\right.$, art. 179) ${ }^{8}$, mantidos até hoje respectivamente nos artigos 52, X e 97 da Constituição de 1988.

Cumpre recordar que nas hipóteses de ação direta, de controle da constitucionalidade por via principal, por decorrência lógica do objeto da demanda, ou seja, examinar a validade do ato normativo impugnado, sua compatibilidade em face da constituição, e por expressa previsão no art. 28 da Lei no 9.868/99, a decisão sempre terá caráter geral, eficácia contra todos e efeito vinculante em relação aos órgãos do Poder Público nas esferas federal, estadual e municipal ${ }^{9}$; mesmo quando se valer da técnica de interpretação conforme a constituição, declarando a inconstitucionalidade parcial sem

\footnotetext{
${ }^{6}$ Sobre o constitucionalismo semântico da época do regime militar ver SARMENTO, Daniel. Por um constitucionalismo inclusivo. Rio de Janeiro, Lumen Juris, 2010, pág. 53-84.

7 Ver por exemplo a Resolução 5/2012 que suspende a execução de parte do $\S 4^{\circ}$ do art. 33 da Lei no 11343/2006 que vedava na hipótese a conversão da pena corporal em pena restritiva de direitos, declarada inconstitucional em decisão definitiva do STF no $\mathrm{HC}$ n $^{0}$ 97.256/RJ.

${ }^{8} \mathrm{~A}$ cláusula de reserva de plenário diz respeito ao controle difuso, portanto, foge ao escopo do presente trabalho. Vale comentar, no entanto, que a entendo exigivel mesmo quando em debate a conformidade constitucional de norma anterior à Constituição vigente, por se tratar de caso de inconstitucionalidade superveniente e que o tema deu causa a edição da Súmula Vinculante $n^{0} 10$ - Viola a cláusula de reserva de plenário (CF, art. 97) a decisão de órgão fracionário de tribunal que, embora não declare expressamente a inconstitucionalidade de lei ou ato normativo, afasta sua incidência, no todo ou em parte.

${ }^{9}$ Embora o Poder Legislativo não tenha sido expressamente referido não faz sentido exigir que na hipótese de edição de um novo ato normativo, substancialmente idêntico, em lugar de fazer uso de reclamação seja necessário propor, processar e julgar nova ação direta.
} 
redução de texto. Como observou Barroso (2009, pág. 193) a decisão que declara a inconstitucionalidade em ação direta tem autoridade de coisa julgada e vincula até mesmo o STF, mas a que julga o pedido improcedente vincula os demais órgãos, mas não ao Supremo Tribunal, que ainda poderá, querendo, rever o decidido. A excepcionalidade e extensão dos efeitos da Jurisdição constitucional exercida por via principal justificam questionar, afinal, que estilo de fundamentação é exigível para que se confira credibilidade e transparência às decisões?

\section{ARGUMENTO COMO FONTE ÉTICA DE LEGITIMAÇÃO}

A carga argumentativa não é um simples imperativo funcional da técnica decisória. A motivação é um componente essencial da legitimação do próprio meio jurídico. Interessa, portanto, antes de prosseguir, explicitar o sentido de Direito adotado nestas reflexões. O conceito Direito expressa uma dimensão "prática", na qual tem relevo as noções de trajetória, temporariedade, contexto e tradições; e uma dimensão de "ordem", na qual sobressaem as noções de racionalidade e de sistema. A dimensão prática supõe, para equilibrar-se, para manter-se: "adaptabilidade", o que envolve o "conhecimento do mundo", experiência; e "invenção", que envolve a crítica da realidade conhecida, experimentação. A dimensão de ordem, por sua vez, supõe "unidade interior", o que tem a ver com o plano teleológico de identificação de finalidades, intenções e projetos; e "adequação valorativa", o que envolve o plano axiológico de seleção de valores, escolhas morais.

A "normatividade-juridicidade" própria e produzida pela ordem jurídica é um meio que rege o subsistema de direitos, que é um subsistema o qual, ao lado do subsistema econômico, regido pelo meio "dinheiro-moeda" e do subsistema tecnocráticoadministrativo, regido pelo meio "poder-força", regula as relações sociais. Há uma coordenação e uma interferência recíproca entre os subsistemas do sistema social total e há outros subsistemas, como o moral e o ideológico. Porém, a relação entre moral e direito será abordada adiante, e a influência do domínio e da manipulação do saber e da informação nas relações sociais e no direito embora extremamente relevante, é tema que foge aos propósitos deste artigo.

É possível falar em ordem para significar cada subsistema, pois todo sistema é, em si, uma ordenação, e falar em "ordens institucionais do mundo da vida". Habermas opta por uma divisão binária "esfera da vida privada", na qual as relações sociais base são de trabalho e de consumo, reguladas pelo sistema econômico e dominados pelo meio "dinheiro" e "esfera da opinião pública" na qual as relações bases são as de contribuinte e de cidadão, regulados pelo sistema político-burocrático-administrativo e dominados pelo meio poder (HABERMAS, 2010. pág. 786 e 840).

Acompanhando Hegel (1979) é possível considerar três ordens institucionais em lugar de duas. A “família”, esfera íntima na qual as relações se estabelecem pela eleição de afinidades e correspondências afetivas e para cuidado e auxílio mútuo, campo da vida privada; a "sociedade civil", esfera pública, mas não governamental (embora eventualmente o estado intervenha como agente desenvolvendo direta ou indiretamente atividade econômica), na qual as relações se estabelecem pelo imperativo de competir pela satisfação das necessidades da sobrevivência e por preferências, campo da produção (relações de trabalho e de consumo); e "sociedade política", esfera pública institucionalizada (mas não necessariamente governamental) na qual as relações são, em 
regra, involuntárias, como no plano privado da produção (só excepcionalmente a nacionalidade é fruto de escolha), e se estabelecem pelo imperativo de cooperação e entendimento mútuo, campo da formação da opinião e da vontade (relações fiscais e de cidadania).

Já o sujeito do drama social é tanto o indivíduo, tomado em um sentido eminentemente psicológico, inserido em um mundo circundante, a coletividade, a ele oposta e composta de outras individualidades, cujo espaço vital é a casa, campo da interioridade e da existência; quanto é a pessoa, assumida em um sentido ético, de membro da comunidade (MASSÚ, 2009), inserido na esfera pública, espaço da busca de realização da res publica, da formação e da preservação de um patrimônio comum, cujo espaço vital é a comuna, campo da exterioridade e da sobrevivência, fora da casa, na cidade, na praça, em público (SALDANHA, 2005). A família, vale observar, foge a este esquema simplista porque é coletivo situado dentro da casa, na esfera privada das eleições por critérios afetivos.

O Estado constitucional moderno, produto da mentalidade burguesa laica-racional redefiniu a relação indivíduo-coletividade fazendo do indivíduo "pessoa-cidadã", posição jurídica, reunindo poderes, faculdades, direitos e deveres; e da coletividade "Estado", sistema de funções explicitados na formalização jurídica objetiva. Na idade média predominava a esfera privada os laços pessoais, a cultura do segredo (arcana), uma mentalidade aristocrática, voltada para o passado, para a permanência; na idade moderna predomina a esfera pública, os laços impessoais, a cultura da transparência (conhecimento aberto e acessível), uma mentalidade democrática voltada para a posteridade, de otimismo, consideravelmente abalado pela consciência ambiental, porém ainda indiscutivelmente marcada pela publicização do saber. Essa forma de vida e de visão de mundo do nosso tempo impõe ao judiciário, um poder tradicional, toda uma readaptação de ritos e de estilo, reclama romper com as raízes aristocráticas, com o segredo e com o hermetismo da gestão monopolista do saber, em favor de visibilidade, tanto na exigência de motivação quanto na necessidade de que o estilo decisório seja vertido em um discurso acessível.

Pessoa é ser plural (em um mesmo indivíduo se reconhece mais de uma pessoa) nascida em uma comunidade linguística, já que adquire consciência de si e tem a sua identidade formada no espaço de comunicação (dado que escutamos antes de ver, antes de nascer até, somos concebidos imersos na linguagem que nos conecta além do abrigo materno, antes de sermos socialmente estamos e temos língua, embora ainda inaptos para comunicação) e inserida na realidade (organiza as relações com os seus semelhantes sob o "pano de fundo de um mundo da vida compartilhado") ${ }^{10}$. O desenvolvimento da personalidade de cada um depende da liberdade dos outros, depende da alteridade. Com consciência moral autônoma o indivíduo critica, julga e aspira justificação e a

\footnotetext{
${ }^{10}$ A complexidade de estabelecer um sentido para o humano seja derivando do individuum ou de persona pode ser medido por um pequeno exercício de resgate de expressões que designam aspectos da existência: Bios (grego) vida, existência, unidade dotada de sentido. Zôion (grego) Zoé - ser vivo, animal. Psukê, psiquê - sopro. Anima (latim) - sopro, alma, princípio espiritual da vida (oposto a corpus). Animus - princípio superior que rege a anima. Pneumo (grego) Spiritus (latim) Animans (alis), por derivação o que tem vida. Derivando em equaninus - espírito moderado e magnaninus, espírito generoso. Androo (grego) transformar em homem. Humano - latim medieval, tradução do grego pela Igreja na vulgata (aparentemente não derivado de homós - semelhante, igual), derivado do latim homo, indivíduo da espécie humana, gênero humano.
} 
formalização do direito é permeada pela moralidade e ao mesmo tempo é garantidora dos valores morais que toma para si.

E a noção de pessoa tem uma dimensão ética, abriga também suposições sobre identidade. Todo pronunciamento formulado no presente ou no passado só pode ser imputado quando o ouvinte pode atribuir identidade ao orador, podendo criticar a pretensão de validade de agora ou de então (HABERMAS, 2009, pág. 329) ${ }^{11}$. A suposição de identidade é condição, igualmente, para outros compromissos relacionados com a apresentação ou aceitação de uma pretensão de validade, sejam eles diretamente ligados ao prosseguimento da argumentação, sejam, outras obrigações, derivadas, relevantes para a ação com as quais um orador pode comprometer-se com um ouvinte para o futuro, como no caso de promessas.

O "eu" social precisa do "outro", da diferença para formar a "consciência de si", precisa do estranhamento, da distância, mas também depende do "outro" para sobreviver seja vencendo-o na competição, seja se entendendo na cooperação. A preservação da consciência obriga a dar atenção à diferença, a coexistência reclama tolerância para com o diferente e atenção com quem é afim-próximo-semelhante. Fora do "eu" estão reunidos em tensão o "outro" e o "semelhante", alguém que é não-eu e é meu próximo, indispensável e nunca acessível por inteiro, inclusive porque le persone sano mobili e se influenciam reciprocamente.

Todo sujeito é constituído de necessidades, discernimento, preferências, trabalho e linguagem. Necessidades e trabalho (ação - poder de criar) são naturais, estão no nível do "animal" diluído na natureza; linguagem (capacidade de comunicação), discernimento (capacidade de compreensão) e preferências (arbítrio) são culturais, estão no nível do "racional". Para Emanuel Lévinas (1993) o "animal racional" humano, enquanto "animal" funde-se com a natureza; enquanto "racional" se vê ofuscado na luz das ideias (conceitos, encadeamentos lógicos e estruturas). A subjetividade visível na "máscara" chamada "pessoa" tem consciência de "si" e do "outro". A consciência da qual não se pode fugir é um estado do ente/ser. É uma modalidade ontológica que tem no "começo/criação" o seu ponto essencial. Começo é atividade, ação, envolve instituir o presente. O conteúdo da consciência é o presente ou é representação (memória, narrativa, história, compartilhamento) ${ }^{12}$.

O eu-indivíduo-pessoa consciente de si e que age em nome próprio e em nome dos demais, ator e autor é condenado à liberdade, é cativo da necessidade e fadado ao convívio. O "eu" nada conhece aquém da liberdade e fora da necessidade, mas convive, portanto, pode ser questionado pelo "outro", próximo ou distante. Essa conexão com o "outro" está na raiz da responsabilidade independente da escolha, antecede à liberdade, está ligada ao Bem absoluto, que dispensa intencionalidade. Não se trata de servidão, não

\footnotetext{
11 Aqui residem alguns dos problemas da hermenêutica filosófica. Primeiro, enquanto hermenêutica, tende a supervalorizar o dito subestimando a cena; segundo, por uma dependência contextual da apreensão de sentidos, partindo de uma pré-compreensão apoiada na tradição, o que não deixa de ser um consenso prévio de sentido que, porém, não é determinado. E toda tradição é um fato de autoridade. Ora, como observou Habermas "só podemos criticar as tradições respectivamente particulares na medida em que nós mesmos pertencemos ao contexto tradicional abrangente de uma língua" No A Lógica das Ciências Sociais, Petrópolis, Vozes, 2009, p. 329. Entretanto, nada assegura que o entendimento que se faz no compartilhamento da tradição seja fruto de uma comunicação não distorcida pela manipulação ou pela violência. Para fugir desta cilada é preciso se valer da idéia reguladora contrafactual de uma comunidade de interpretação universal, ilimitada e livre de dominação.

${ }^{12}$ A vivência do presente é individual, produto de autorreflexão, a representação possibilitada pela memória, no entanto, carrega de modo indistinto o que foi autorreflexão e o que foi compartilhamento.
} 
há negação da liberdade. A subjetividade (a essência do sujeito) está fora e aquém da alternativa entre determinismo e servidão.

Deixando de lado o problema da bondade e da honestidade, virtudes que regem relações para além do espaço público e fixando-se na questão da justiça, pois é está a finalidade do sistema de Direitos e assumindo que as experiências de socialização impõem cooperação em base ética, tem-se que "as questões de justiça podem, com efeito, ter uma resposta racional e há que estabelecer as regras de argumentação ou os princípios morais que as podem fundamentar" (HABERMAS, 1991, pág. 181).

$\mathrm{Na}$ jurisdição o sujeito - pessoa investida de autoridade - dialoga com os outros sujeitos do processo, as partes, mas também com cada um, isto é, com a sociedade, situada na perspectiva de observadora, com o público. A interlocução direta com as partes do processo e indireta com a sociedade são igualmente relevantes e precisam ser consideradas no estilo de motivação do ato decisório.

Ordenamento, vale esclarecer, é tomado aqui como expressão de qualquer meio regular e estável de realização de atos que favorece a previsibilidade, produz hábitos, expectativas, normas e seus correlatos os desvios. Neste sentido também se pode falar em ordem política, estabilizadora e racionalizadora dos vínculos entre cidadão e governante, ordem econômica, no que diz respeito aos vínculos entre produtores (empresários e trabalhadores igualmente considerados nesta categoria) e consumidores e em ordem ética, envolvendo os vínculos estabelecidos entre as pessoas com abstração das ordens particulares, isto é, pela condição natural de sermos eu e outro. Porém, é importante perceber que a ética precede o Estado e é fonte da sua legitimidade. "O Estado, poder-seia dizer, só é justificável como veículo ou instrumento da ética" (BAUMAN, 1998, pág. 69).

Ética, cabe a insistência, aqui vem tomada no sentido de responsabilidade recíproca pelos outros, independente de semelhança e de proximidade. Toda ética supõe uma expectativa relativa ao modo do "um" se relacionar com os "outros" que é generalizada e, no limite, por vezes, pretende ser universal. A linguagem que conecta e a necessidade que compele à conexão trazem a consciência do direito e do dever de respeito e de cuidado, trazem, portanto, corresponsabilidades para com todos, próximos ou estranhos, contemporâneos, antepassados ou gerações futuras.

Mas há padrões éticos particulares no sentido de pontos de vista éticos determinados pela posição do sujeito nas relações sociais. A ética do participante da relação concreta, por exemplo, é moldada por ressentimento e culpa, a ética do mero observador, que é estranho a relação, será moldada pela indignação e pelo dever. Não é preciso ser oprimido ou opressor para repudiar a opressão. O opressor que repudia o faz por culpa o oprimido traz a marca do ressentimento, já o observador age por indignação ou senso de dever. E esse olhar ético da parte do observador, aliviado da sobrecarga moral, da culpa, permite reinterpretar e reconstruir as instituições. Assim é que o direito serve e se serve da ética. A indisponibilidade, a impessoalidade e a generalidade da norma jurídica desoneram o sujeito de um exame moral prévio a cada atitude ou escolha no mundo da vida compartilhado. Serve-se porque é a ética que fundamenta o sistema de direitos oferecendo os princípios de justiça que legitimam a ordem jurídica.

$\mathrm{Na}$ medida em que o fundamento do direito está situado fora do sistema jurídico, repousa na ética, interessa tomar posição quanto a qual ética é legitimadora de um sistema que se pretende democrático. Neste plano não podem ser ignorados, nem o fato da opressão (a sociedade é excludente), nem o fato do pluralismo (a sociedade é heterogênea). $O$ reconhecimento da opressão me afasta de uma ética monológica de 
convicção, em favor de uma ética dialógica, de responsabilidade para com o vulnerável, o oprimido, que tem menor acesso aos meios institucionais de condução dos interesses comuns, referida à história; o reconhecimento do pluralismo, da coexistência de mais de uma concepção razoável sobre o interesse público (razoável significando tolerante, no sentido de aceitação da divergência e renúncia a meios violentos ou à manipulação para defesa dos pontos de vista), me afasta de uma justiça substantiva em favor de uma justiça procedimental, dialogada e pragmática. Uma justiça capaz de vencer a injustiça da totalidade social que surge não da história, mas como julgamento da história ${ }^{13}$.

A ética pela qual se opta é uma ética do discurso (ALEXY, 2001, pág. 304), inserida no plano de uma filosofia moral (a pessoa é e tem um fim em si mesmo e é capaz de vontade) e prática (há historicidade objetiva, com sujeito que não se dilui nas estruturas do real); pós-metafísica (reabilita a razão prática pela crença na racionalidade como meio apto a orientar a interação); universalista (oposta ao particularismo utilitarista); que admite correção (rejeitando o relativismo cético pós-moderno); e comunicativa (sustentada na força da linguagem como veículo necessário da produção de sentido que possibilita ações e interações transformadoras da realidade).

A racionalidade subjacente a esta escolha é uma racionalidade comunicativa que pode atender: ao modelo que visa o entendimento, a coordenação de interesses, tendo por destinatário do discurso a comunidade ideal de fala, no momento de fundamentação, quando prevalece um estilo argumentativo de convencimento; ou ao modelo que visa acordo, o sucesso, tendo por destinatário do discurso argumentativo uma comunidade real, no momento da aplicação, quando prevalece um estilo argumentativo de persuasão. O discurso de fundamentação, por sua vez, ainda pode ser desdobrado para que se diferencie a parte de fundamentação "a" - deôntica - de entendimento sobre a natureza das coisas e dos fenômenos, com abstração da história e a parte de fundamentação "b" axiológica - de entendimento sobre os valores e atitudes, que é histórica (APEL, 2005).

Importante reafirmar, mais uma vez acompanhado Alexy (1991), que o discurso jurídico é um caso do discurso prático geral e precisa satisfazer exigências de justificação tanto externa (das premissas usadas) quanto interna (da argumentação em si). Na condição de um caso de discurso prático o discurso jurídico está submetido às regras de amplitude (ninguém deve ser tolhido de participar), sinceridade (os participantes devem apresentar como argumento algo em que acreditam), não contradição, liberdade de discussão (igual acesso à informação, ausência de manipulação e de coerção) e de compromisso de justificação (expor razões quando confrontado) e de universalidade potencial. Além do mais, toda norma jurídica, um imperativo que estabelece, rege e sanciona certo modo de se conduzir, reclama, do pondo de vista da justificação externa, uma norma universal validadora a qual possa expressar, pelo menos, a ideia de que normas justas devem ser obedecidas $^{14}$; bem como reclama, do pondo de vista da justificação interna ou aplicação, coerência (com o sistema ao qual está inserida) e consistência (com os aspectos empíricos da situação). O cuidado com a fundamentação é importante para que se possa controlar o risco antidemocrático do "decisionismo" voluntarista.

Quem fizer uma afirmação normativa que pressuponha uma regra com certas consequências para a satisfação dos interesses de outras pessoas

\footnotetext{
13BAUMAN, op. cit.

14 O conteúdo do justo e os critérios de aferição do justo, apoiado na autoridade do sujeito que afirma a norma, ou na finalidade objetivamente aferível da norma confrontada em um exame de adequação no caso, ou em face de atributos do procedimento empregado na produção e aplicação não importa, a regra primária estará presente.
} 
deve ser capaz de aceitar essas consequências, mesmo na situação hipotética em que esteja na posição dessas pessoas. (ALEXY, 1991, pág. 197)

Problemas de aplicação não se resolvem apenas pela construção-revelação da norma válida incidente no caso segundo parâmetros prévios de um sujeito autorizado - o legislador como regra, o governante ou o juiz, ocasionalmente. O contexto de aplicação opera à luz de princípios e contempla uma carga de indeterminação que não é nada desprezível. Todavia, na ética do discurso o que se destaca é a força justificadora de características presentes nas situações nas quais a cooperação é possibilitada pela linguagem. $\mathrm{Na}$ aferição do que é aceitável, correto, e, portanto, capaz de infundir legitimidade, caberá distinguir entre o contexto de apreciação da validez das normas e o contexto de adequação das decisões que aplicam as normas tidas como válidas. $\mathrm{O}$ ônus argumentativo para fundamentar a validade e para justificar a aplicação é diferente.

Nos dois contextos, porém, sobrepõe-se uma razão justificadora universalizável própria dos processos de convivência sob responsabilidade recíproca, que vem a ser o ônus de demonstração continuada de respeito pela equidade. A tarefa de justificação é, pois, um processo contínuo, sem limite de tempo ou de participantes. Conforme observou Pontes de Miranda:

[...] no corrigir a excessiva aderência ao passado, a perniciosa estabilidade, ou as fugas ao encadeamento histórico, subversivas e violentas, o Direito, ainda que empregue outras considerações, em verdade provê à moderação, ao equilíbrio, à reta solução, que a etimologia revela (directum, ius) (1960, pág. 163).

Esta coesão entre fundadores, contemporâneos e gerações futuras, aceitos como partes de uma mesma tradição, com suposições de identidade compartilhada e envolvimento num único e mesmo processo argumentativo, serve para corrigir o déficit natural de legitimidade do momento inaugural do sistema, quando não há como estabelecer um procedimento racional-discursivo antecedente garantidor do caráter democrático da situação constituinte, porém, na sequência, é a demanda por equidade, ou imparcialidade como prefere Günther, que assegura a integridade do sistema, servindo de anteparo contra o autoritarismo voluntarista que é o grande risco advindo da abertura do direito proporcionada pela ruptura com o positivismo no constitucionalismo contemporâneo.

Processos coletivos de aprendizagem moral necessitam de um princípio que obrigue normativamente a considerar novas experiências e a modificar as concepções morais que até então eram consideradas justificáveis. Este princípio não pode ser outro senão o da imparcialidade, e isso tanto no sentido universal-recíproco como também no sentido aplicativo. Deve haver um ônus argumentativo para aquele que, apesar da descoberta de novos sinais característicos de uma circunstância, quiser dar continuidade a uma subsistente prática de tratamento desigual (igual). Este ônus argumentativo há de ser fundado em um princípio que vincula a aplicação de uma norma (da qual resultem primeiramente as perspectivas, segundo as quais coisas iguais têm de ser tratadas de forma igual e coisas desiguais, desigualmente) à consideração de todos os sinais característicos da situação. Apenas a 
mera revisão de modelos de interpretação, sem referência a normas que precisam ser fundamentadas e aplicadas de forma imparcial, ainda não consegue pôr em movimento um processo de aprendizagem. A nossa prática moral mudará tão-somente quando se impuser o entendimento de que já não podemos aplicar adequadamente uma norma e de que a sua não-aceitação como válida, diante de novos sinais característicos ampliados com esse novo âmbito de aplicação, contrariará o interesse de todos os afetados. (GÜNTHER, 2004, pág.99).

Interessante observar, ainda com Pontes de Miranda, que a nota distintiva da atividade jurisdicional não é a interpretação nem a aplicação do direito. Todos interpretam e muitos aplicam: o legislativo formula sobre o sentido e o alcance das disposições constitucionais quando examina a viabilidade de uma proposição normativa; o executivo estabelece o sentido e o alcance de regras jurídicas na execução dos poderes inerentes ao governo e à administração, intervindo no domínio econômico ou organizando-se para oferecer serviços essenciais. O que diferencia o judiciário é o poder de dirimir controvérsia sobre a validez e a aplicação do direito em definitivo. É o poder de julgar. Por isso não existe uma prioridade ou hierarquia valorativa entre aquele que presta jurisdição e as partes que a provocam. A vontade, as razões e os argumentos selecionados pelo legitimado para agir ou para refutar a ação tem o mesmo peso que as razões que motivam a decisão que poderá vir a ser reforçada pela autoridade de coisa julgada.

Não se perca de vista que as normas jurídicas, sejam elas produto da atividade legislativa, sejam produto da atividade jurisdicional, "são fundamentadas e aplicadas em discursos institucionalizados"; assim, estão submetidas a uma adequação situacional limitadora. "Normas jurídicas gerais e singulares precisam, portanto, derivar de discursos capazes de ser concluídos por meio de uma decisão. Com isso, diferentemente do discurso prático, eles estão sob condições de exiguidade de tempo e de conhecimento incompleto" (GÜNTHER, 2004, pág. 368). Todavia, não se ignora que, diante de problemas concretos que exigem julgamento uma decisão tomada sob limites de tempo, dos sujeitos participantes e do objeto alcançado, limites estes que são inerentes à técnica jurídica e vem traçados no procedimento, é melhor do que uma indefinição permanente.

A seguir o que se pretende é examinar, a partir de alguns casos práticos, o modo de fundamentar as decisões do Supremo Tribunal Federal quando investido da função de estabelecer um conteúdo normativo, agindo na condição de fiscal da constitucionalidade dos atos normativos em abstrato, sem descuidar da constatação de que: o sistema de direitos reclama uma fundamentação ética; que na democracia esta ética pode e deve ser apoiada nos atributos do processo de aprendizagem e comunicação, voltado para o entendimento; o discurso jurídico é um caso de discurso prático em geral; a justificação do discurso jurídico contempla, com ônus argumentativo, diferentes contextos de fundamentação e de aplicação; e não há uma prioridade do Estado provocado em face sociedade provocadora do exercício do poder jurisdicional ${ }^{15}$.

15 Com base em Alexy é possível dizer que são regras de justificação do discurso prático em geral: 1) quem faz uma afirmação normativa pressupondo uma regra com consequências para terceiros tem de aceitar essas consequências na hipótese de se ver na mesma situação; 2) as consequências das regras para satisfação de interesses de cada um têm de ser aceitas por todas as pessoas; 3) as regras tem de ser claras e universalmente compreensíveis; 4) regras morais tem de resistir à crítica de compatibilidade tanto com sua gênese histórica quanto com o contexto atual; 5) devem também ser aceitáveis para o orador individualmente, com base num exame autocrítico. São regras do discurso jurídico: 1) todo julgamento tem de ser apoiado em ao menos uma norma universal; 2) além de seguir logicamente ao menos uma norma universal, tem de ser reforçado por afirmações internamente coerentes; 3) sempre que houver 
Exige-se que a força persuasiva (pelo ângulo da aplicação) e demonstrativa (pelo ângulo de fundamentação) de qualquer decisão com efeito geral e vinculante seja maior. Uma decisão desta ordem tem de oferecer uma descrição a mais completa possível da situação e tem de demonstrar a aceitabilidade das razões para os potencialmente afetados, o que obriga indicar os participantes do processo decisório, a indicação dos alcançados pela decisão, a justificação dos elementos que autorizam a generalização e a demonstração de satisfazer o imperativo de equidade; isto sem se desobrigar do ônus comum a qualquer decisão judicial de na parte dispositiva orientar concretamente a ação, resolvendo o caso. Acrescente-se que o magistrado investido da jurisdição constitucional concentrada, exercida em abstrato por via principal, não está dispensado de manter e de demonstrar imparcialidade. A singular natureza objetiva do processo não afasta a exigência de um exercício de distanciamento e autoriza considerar comprometido qualquer ministro que tenha tido envolvimento direto na formulação ou na aprovação do ato normativo questionado.

Antes de dar sequência convém registrar que o formato das decisões da parte dos órgãos jurisdicionais colegiados no Brasil, já resulta em um deficit de fundamentação na medida em que é designado um relator que fica encarregado de expressar as razões que conduzem a formação da decisão por seus pares, razões essas muitas vezes substancialmente distintas, mesmo quando há convergência de resultado, e não há norma que obrigue incorporar os debates, inclusive sustentações orais das partes, no ato decisório, pelo contrário, frequentemente o acórdão lavrado contém apenas a ementa síntese, o relatório prévio ao julgamento e o voto escrito do relator também elaborado previamente e a certidão de julgamento apenas traz uma breve descrição do resultado com simples notícia de quais partes fizeram uso da palavra em sustentação oral, quando há.

Claro que o atual Código de Processo Civil (Lei no 13.105/2015) representa um avanço importante, na medida em que, dispondo sobre a ordem dos processos nos tribunais determina expressamente que o voto vencido deve ser declarado e integra o acórdão para todos os seus efeitos, inclusive prequestionamento (art. $941 \S 3^{\circ}$ ). Todavia, limita-se a exigir que todo acórdão contenha ementa (at. $943 \S 1^{\circ}$ ), mantendo a estrutura de relatório, voto e acórdão (art. 931), embora considere as notas taquigráficas como substitutivas do acórdão, no caso da sua não publicação em até 30 dias contados da Sessão de julgamento (art. 944).

Porém, neste aspecto, o Regimento Interno do STF é mais transparente que a regra processual comum na medida em que o art. 93 prevê que "as conclusões do Plenário e das Turmas, em suas decisões, constarão de acórdão, do qual fará parte a transcrição do áudio do julgamento" e o art. 96 estabelece que "em cada julgamento a transcrição do áudio registrará o relatório, a discussão, os votos fundamentados, bem como as perguntas feitas aos advogados e suas respostas, e será juntada aos autos com o acórdão, depois de revista e rubricada". O ideal, contudo, seria dispensar o acórdão e considerar as sustentações e debates, que em regra não são publicadas, como parte integrante da decisão.

dúvida sobre qual norma deve prevalecer é preciso apresentar ou formular uma ou tantas regras quantas forem necessárias para resolver o problema. 


\section{ALGUNS JULGADOS SIGNIFICATIVOS}

Após uma fase que se poderia chamar de consolidação institucional, situada a partir da promulgação da constituição até a edição da emenda constitucional 45 , o Supremo Tribunal Federal tem sido, como já foi dito, chamado a decidir sobre muitos temas centrais da convivência de forma concentrada, seja por Ação Direta seja por Arguição de Descumprimento de Preceito Fundamental. Não é propósito nem caberia fazer aqui um levantamento quantitativo ou com pretensões exaustivas dessa intensa atividade. Para o fim de chamar atenção para o estilo argumentativo e para a abertura da fundamentação aos argumentos da sociedade basta rememorar alguns poucos julgados.

Por meio da Ação Direta de Inconstitucionalidade $n^{\circ}$ 3.999-7, julgada em 12/11/2008, a regulamentação, por parte do TSE, para o procedimento de justificação de desfiliação partidária e de perda do cargo eletivo por quebra de fidelidade (Resoluções 22.610/07 e 22.733/08) foi examinada. A discussão foi desdobramento das decisões proferidas pelo próprio STF no julgamento dos Mandados de Segurança 26.602, rel. min. Eros Grau; 26.603, rel. min. Celso de Mello; e 26.604, rel. min. Carmen Lúcia. Por maioria, vencido o ministro Marco Aurélio Mello, foi rejeitada preliminar de não conhecimento da ação e também por maioria, vencidos os ministros Eros Grau e Marco Aurélio, foi julgado improcedente o pedido com reconhecimento indireto da constitucionalidade dos atos normativos na linha do voto do relator ministro Joaquim Barbosa.

A decisão na ADI 3.999-7 tem relevância porque enfrentou, em sede de controle concentrado, o tema sensível das condições possibilitadoras da livre expressão da soberania popular que, como dito acima, fora tema dos Mandados de Segurança que motivaram a edição das Resoluções questionadas. Como pano de fundo foi debatido o outro tema relevante do ponto de vista da arquitetura democrática que é o do alcance do poder regulamentar da Justiça Eleitoral.

O tema e o calendário eleitoral justificavam que a questão fosse decidida sem demora, tendo sido adotado o procedimento previsto no art. 12 da Lei $\mathrm{n}^{\circ}$ 9.868/1999, e esta circunstância pode ter contribuído para o fato de que não houve ingresso de amicus curiae, assim como também não houve convocação de audiência pública. As informações foram prestadas pelo Presidente de TSE, defendendo que não havia violação do princípio da separação de poderes com intromissão em matéria reservada ao Legislativo, porque não se tratava de inovação normativa, mas simples acatamento dos procedentes do Supremo Tribunal Federal, com destaque para o teor do voto do ministro Celso de Mello no MS 26.603, que mencionou explicitamente a possibilidade de edição pelo Tribunal Superior Eleitoral de resolução destinada a regulamentar a consequência derivada pelo decisum, isto é, a perda do mandato pelo parlamentar que se desfiliava sem justa causa do partido pelo qual fora eleito. Nesta mesma linha segundo breve registro do relatório segue a defesa do ato pelo então Advogado-Geral da União Dias Toffoli.

No julgamento da ADI 3.999-7 o argumento que veio a prevalecer, trazido pelo relator, ministro Joaquim Barbosa, que havia ficado vencido no julgamento dos Mandados de Segurança que estabeleceram a virada da interpretação constitucional na matéria, foi utilitário. Em nome da efetividade da interpretação constitucional que foi construída e da preservação da autoridade da Corte, posta em cheque pela omissão legislativa, estaria excepcionalmente justificada a atuação reguladora da Justiça Eleitoral. O relator afirma seu entendimento de ser "o judiciário mal equipado para resolver a instabilidade originada da perda de mandato eletivo", sustentando ser "o debate 
legislativo o ambiente adequado" para enfrentar algumas questões delicadas que derivam da posição assumida pelo STF nos precedentes, tais como decidir se a vista da legitimidade reconhecida do suplente para questionar o mandato se o eleitor não teria igual poder? Se a anuência do partido seria saneadora do desequilíbrio gerado na representação política pelo divórcio entre a partilha produto do voto e a distribuição de poder fruto das decisões individuais dos parlamentares? Quais critérios deveriam orientar a aferição de justa causa? E qual procedimento seria adequado para possibilitar contraditório e ampla defesa àquele que está sob iminência de perder o mandato?

Merece destaque que o relator invocou o princípio da disciplina colegial ao justificar seu voto, aduzindo que os julgadores precisam estar atentos às limitações institucionais do Poder Judiciário, o que inclui as limitações inerentes ao fato de compor um órgão colegiado cuja vontade manifestada não se confunde com a vontade individual dos seus membros. Por tais razões buscou garantir a efetividade da decisão que explicitou a complexidade da relação eleitoral, pois o exercício do sufrágio gera uma expectativa do eleitorado relativa à representação popular, expressa a percepção do eleitor sobre a fidelidade. De fato, os precedentes, com base no art. $14, \S 3^{\circ}$, V da Constituição, foram apoiados muito mais na noção de fidelidade ao eleitor do que de fidelidade partidária. $\mathrm{O}$ STF afastou a incidência do art. 55 da Constituição de 1988 e distinguiu a sanção por ilícito de sacrifício do direito como consequência de uma atitude lícita a desfiliação partidária. A perda do direito de continuar a exercer o mandato decorreria da opção livre pela desfiliação em confronto com o direito do partido de manter a representação resultante da manifestação da vontade popular por meio do voto dos eleitores. Para o ministro Joaquim Barbosa a decisão supervaloriza os direitos dos partidos políticos.

Também o ministro Lewandowski, que divergira no julgamento dos Mandados de Segurança, por entender que não era caso de direito líquido e certo, após reconhecer estar superada a questão pela decisão do Plenário, acompanhou o voto do ministro Joaquim Barbosa, acentuando que "o TSE seria obrigado a dar concreção à decisão do Supremo Tribunal, prolatada em sede de interpretação constitucional, justamente em razão da eficácia irradiante desse tipo de decisão para todo o sistema jurisdicional".

Os ministros Eros Grau e Marco Aurélio reafirmaram nos seus votos divergentes as razões expostas quando divergiram na decisão dos Mandados de Segurança. Os ministros Menezes Direito, Carmen Lúcia (que havia sido relatora de um dos precedentes invocados), Ellen Gracie, César Peluso, Gilmar Mendes e Celso de Mello acompanharam o voto do relator sem maiores considerações, sempre na linha da busca de "efetividade jurídica da própria constituição" (voto da ministra Carmen Lúcia), ou em nome do "desafio da efetividade" (voto do ministro Gilmar Mendes), com destaque para a garantia de devido processo (voto do ministro César Peluso) e para a reiteração, por parte do ministro Celso de Mello, cujo voto no Mandado de Segurança $\mathrm{n}^{\circ} 26.603$ foi múltiplas vezes citado pelos seus pares, do argumento de fundo de que "a prática da infidelidade partidária, ao propiciar ilegítima alteração do resultado das urnas fora do processo eleitoral, provoca, com tal consequência, gravíssima lesão ao princípio democrático". Vale mencionar que o ministro já havia ficado vencido nesta tese quando do julgamento do MS n ${ }^{\circ}$ 20.927, relatado pelo ministro Moreira Alves, em 11/10/1989, precedente que foi superado em 2007.

$\mathrm{O}$ voto que mais chama atenção, ao lado do voto condutor, evidentemente, é o proferido pelo ministro Ayres Brito que busca fundamentar o poder regulatório da Justiça Eleitoral a partir da dinâmica democrática. O voto destaca que a base do poder regulamentar do TSE decorre de "o vínculo entre eleição popular e democracia", 
valendo-se da metáfora de que "a eleição popular é a chave de ignição da democracia representativa", е о "vinculo que se instaura entre eleitores, candidatos e partidos políticos" se entrelaçarem no processo eleitoral protegido pela Justiça Eleitoral, a quem incumbe planejar, instruir, colher voto, apurar, divulgar resultados, proclamar os eleitos e julgar as demandas daí resultantes. Portanto, vai ao tema de fundo e busca justificar a solução do caso para além de argumento da autoridade dos precedentes e do dilema de efetividade em face da situação excepcional surgida com a momentânea omissão legislativa.

Contudo, não se discutiu, por exemplo, o conflito de interesses do legislador a quem incumbia regulamentar os desdobramentos da decisão do STF e a relevância de uma atividade criadora na formulação de definições que concretizem o desenho institucional traçado pelo elenco de direitos políticos fundamentais, diretamente relacionado com o estabelecimento de limites no funcionamento das instâncias dos poderes da República.

Outro julgado digno de comentário é o da $\mathrm{ADI} \mathrm{n}^{\mathrm{o}}$ 3.510, promovida pelo Procurador Geral da República, enfrentando a constitucionalidade de dispositivos da Lei $\mathrm{n}^{\circ}$ 11.105/05 (Lei de Biossegurança). A discussão principal foi sobre a autorização de pesquisa com células-tronco embrionárias em face da inviolabilidade do direito à vida. $\mathrm{O}$ Supremo Tribunal, por maioria (6x5), declarou a constitucionalidade do uso de célulastronco embrionárias em pesquisas científicas para fins terapêuticos. Votaram com o relator ministro Ayres Brito os ministros Ellen Gracie, Cármen Lúcia, Joaquim Barbosa, Celso de Mello e Marco Aurélio, ficaram vencidos parcialmente, em diferente extensão, os ministros Menezes Direito, Ricardo Lewandowski, Eros Grau, César Peluso e Gilmar Mendes.

A defesa do ato normativo foi realizada pelo Advogado-Geral da União Álvaro Ribeiro da Costa que adotou integralmente o parecer do advogado Rafaelo Abritta e o Procurador-Geral da República por ocasião do julgamento, em 29/05/2008, Antonio Fernando Barros Souza, referendou a posição do ex-Procurador-Geral, Cláudio Fonteles, que promoveu ação. Foram admitidos como amici curiae cinco instituições: Conectas Direitos Humanos; Centro de Direitos Humanos - $\mathrm{CDH}$; Movimento em Prol da vida MOVITAE; Instituto Bioética de Direitos Humanos e Gênero - ANIS e Confederação Nacional dos Bispos do Brasil - CNBB, sob o explícito propósito de "adensamento do teor de legitimidade da decisão a ser proferida". Vale notar, neste ponto, que não houve equilíbrio no que toca as teses contrapostas na medida em que foram admitidos quatro amici comprometidos com a tese da constitucionalidade e um apenas comprometido com a procedência da ação. Além do mais o relator lançou mão pela primeira vez da autorização do art. $9^{\circ} \S 1^{\circ}$ da Lei $n^{\circ} 9.868 / 99$ e realizou histórica audiência pública na qual 22 oradores autorizados discorreram sobre os temas submetidos ao juízo constitucional.

O emblemático julgamento se desdobrou em três dias. No dia 05 de março de 2008 falaram o então Procurador-Geral da República, Antônio Fernando Souza, o então Advogado-Geral da União, Dias Toffoli, Leonardo Mundin pelo Congresso Nacional, Ivens Gandra da Silva Martins pela CNBB, Oscar Vilhena Vieira pela CONECTAS e pelo CDH, e Luís Roberto Barroso pela MOVITAE e pela ANIS. Toffoli e Barroso não tardariam a ter assento no STF. Votaram o relator e a ministra Ellen Gracie, pela improcedência total e pediu vistas o ministro Menezes Direito. No dia 28 de maio de 2008, na sequência do julgamento, votaram também pela improcedência os ministros Cármen Lúcia, Joaquim Barbosa e Marco Aurélio, pela procedência parcial os ministros 
Menezes Direito e Ricardo Lewandowski, pela improcedência parcial os ministros Eros Grau e César Peluso, pediu vistas o ministro Gilmar Mendes, que votou na conclusão do julgamento, em 29 de maio de 2008, também pela procedência parcial para interpretação do art. $5^{\circ}$ da Lei $\mathrm{n}^{\circ} 11.105 / 05$ com efeitos aditivos. De fato, a lei questionada regulamenta a questão central apenas neste único artigo $5^{\text {a }}$. Essa insuficiência talvez explique a variação nos votos vencidos que tentavam suprir a omissão regulamentadora sem inviabilizar a liberdade de pesquisa científica (CF, art. 218).

Conforme já se disse o tema central da ação era a possibilidade de usar célulastronco embrionárias na pesquisa científica com fins terapêuticos. A ação tomou a autorização da lei como atentado à inviolabilidade do direito à vida. A defesa da lei girou em torno do direito fundamental de acesso à saúde e ao planejamento familiar e da liberdade de pesquisa científica como caso da liberdade de expressão. Portanto, o debate foi bem além do que despertou mais atenção nos meios de comunicação de massa que foi a discussão sobre o início da vida humana protegida, se o momento da concepção ou do nascimento. De todo modo, no voto que proferiu o ministro Gilmar Mendes, recorrendo a Habermas, reconhece que nessa discussão "fracassa qualquer tentativa de alcançar uma descrição ideologicamente neutra e, portanto, sem prejulgamento, do status moral da vida humana prematura".

Para os fins desta reflexão não importa o resultado do julgamento, o que se pretende destacar é a sua credibilidade, seu poder de conquistar adesão. Também não é viável fazer um exame detalhado dos argumentos usados ao longo das 526 páginas do acórdão, basta destacar as linhas centrais da decisão. O próprio relator buscou oferecer uma síntese das posições contrapostas, em favor da ação representada pela intervenção da Dra. Lenise Aparecida Martins Garcia do Departamento de Biologia Celular da UnB, em favor do que veio a ser o resultado do julgamento, representada na intervenção da Dra. Mayane Zatz, professora de genética na USP.

De um lado havia a crença de que: não há uma vantagem objetivamente demonstrada das células-tronco embrionárias sobre as células-tronco adultas, em termos de desenvolvimento de novas terapias; a auto-constitutividade do embrião o faz protagonista do próprio desenvolvimento, relegando a gestação materna a um papel secundário; a pessoa protegida, com individualidade genética e especificidade ôntica já está presente a partir da fecundação do óvulo humano pelo espermatozoide humano; o processo de fecundação in vitro ou in vida é irrelevante para a definição do ser humano; ser humano embrionário não pode ser posto involuntariamente a serviço das necessidades, ainda que legítimas de outros seres humanos. Do outro lado a crença de que: por serem mais versáteis as células-tronco embrionárias são vantajosas na pesquisa científica de novas terapias; ser vivo, feto e pessoa humana são realidades distintas e inconfundíveis; a constituição só assegura diretamente proteção à pessoa humana; vida merecedora de ser protegida é vida viável; a intervenção materna é essencial no desenvolvimento que opera a passagem de embrião à pessoa humana possuidora de individualidade antropomórfica, com seus desdobramentos ético-espirituais.

Foi declarada a constitucionalidade do uso das células-tronco embrionárias como emanação do direito à vida digna, compreendida como passando pelo acesso à saúde e pelo direito de planejamento familiar. Foi afirmado um direito à felicidade e de viver com dignidade (voto do ministro Celso de Mello), assim como a autonomia da vontade individual em um Estado laico, tomada como compreensiva do direito a empregar técnica de reprodução assistida no planejamento familiar, sem acarretar dever de aproveitamento reprodutivo da vida embrionária gerada in vitro (voto do ministro Joaquim Barbosa). 
Do profundo e ricamente alegórico voto do ministro relator destaca-se: o prestígio à liberdade científica $\left(\mathrm{CR}\right.$, art. 218 e $5^{\mathrm{a}}$, IX) pela afirmação de que a Justiça não está autorizada a dizer que forma de pesquisa básica é mais promissora; a conclusão de que o silêncio constitucional sobre o início da vida humana significa a transferência do poder de dispor para a legislação ordinária; que a proteção constitucional alcança apenas o ser humano tomado como indivíduo desenvolvido, sendo o embrião, pré-implantado, um bem a ser protegido na forma da lei, mas não uma pessoa constitucionalmente protegida; "os momentos da vida humana anteriores ao nascimento devem ser objeto de proteção pelo direito comum"; um "constitucionalismo fraternal" conduz a que, sem desprezo ao embrião in vitro, se prestigie a "firme disposição para encurtar caminhos que possam levar à superação do infortúnio alheio"; desnecessário usar da técnica de interpretação conforme à constituição "para aditar à lei controles que a maioria considerou desnecessários e restritivos às pesquisas e terapias visadas".

Independente de adesão individual ou não aos argumentos é evidente que no caso houve uma fundamentação que buscou o convencimento e aspirou universalidade e equidade. Chama atenção, no entanto, certa reverência ao discurso científico. A Corte parece aceitar que argumentos administrativos e econômicos sejam controláveis por parâmetros político-jurídicos, mas não aceitar que as escolhas motivadas por um discurso embasado na racionalidade científica sejam igualmente controláveis. Em um tempo no qual a sustentabilidade vai se mostrando um problema global, e decisões sobre novas e velhas tecnologias cresce em importância, tamanha reverência a argumentos justificados exclusivamente pela racionalidade funcional cartesiana pode ser desaconselhável.

Muitos outros julgados poderiam ser citados e analisados para ilustrar a posição aqui sustentada, todavia, apenas alongariam em demasiado a exposição. Assim, servem para encerrar os exemplos dois casos de amplo alcance, no plano social e político: o julgamento conjunto da ADI 4277 e da ADPF 132, respectivamente ajuizadas pelo Procuradoria Geral da República e pelo Governo do Estado do Rio de Janeiro, em 2011, e o da MC na ADPF 378, proposta pelo PC do B, convertido em exame de mérito, em $17 / 12 / 2015$.

Em 2011, conduzido pelo voto do Min. Ayres Brito o STF assumiu uma atitude ativa e explicitamente orientada pelo papel de força contramajoritária para ingressar em esfera cercada de profundo desacordo moral protegendo a liberdade de orientação sexual e de escolha sobre modelos de entidade familiar contra discriminações. No acórdão do julgamento, publicado em 18/10/2011, a Corte Suprema deu interpretação conforme a constituição ao art. 1.723 do Código Civil para, em nome do art. $3^{\mathrm{a}}$, IV da Constituição de 1988, afastar qualquer sentido que impeça o reconhecimento de uniões entre pessoas do mesmo sexo como entidade familiar.

Na ADPF 378, por seu turno, o Tribunal foi chamado ao papel de fiador da legitimidade constitucional em meio a uma profunda crise. Provocado por um Partido político com representação no Congresso Nacional a examinar a regularidade de um processo para julgamento de impeachment da Presidenta da República, cuja natureza é eminentemente política, tanto que atribuído pela Constituição à Câmara dos Deputados e ao Senado Federal (art. 86 da CRFB), ao tempo em que outros nove partidos, da base aliada ao governo e da oposição ingressaram com amicus curie (PSDB, PSB, DEM, PT, PSOL, PP, Rede de Sustentabilidade, Solidariedade e PSD, além de, curiosamente, a União Nacional dos Estudantes), o Supremo Tribunal Federal conheceu do pedido, por unanimidade, e colaborou para a normalidade institucional ao antecipar o exame de mérito, estabilizando as regras do jogo, também por unanimidade. Ao fazê-lo os ministros 
se contrapuseram implicitamente à versão governista de que a denúncia por crime de reponsabilidade e seu exame traduzem um golpe de Estado. Vale reproduzir a síntese do julgamento que consta a ata da sessão.

O Tribunal, por unanimidade e nos termos do voto do Relator, rejeitou as preliminares e conheceu da ação. O Tribunal, nos termos do voto do Ministro Roberto Barroso, que redigirá o acórdão: quanto ao item A, por unanimidade, indeferiu o pedido para afirmar que não há direito à defesa prévia ao ato do Presidente da Câmara; quanto ao item B, por unanimidade, deferiu parcialmente o pedido para estabelecer, em interpretação conforme à Constituição do art. 38 da Lei $n^{\circ}$ 1.079/1950, que é possível a aplicação subsidiária dos Regimentos Internos da Câmara e do Senado ao processo de impeachment, desde que sejam compatíveis com os preceitos legais e constitucionais pertinentes; quanto ao item $\mathbf{C}$, por maioria, deferiu parcialmente o pedido para (1) declarar recepcionados pela $\mathrm{CF} / 88$ os artigos 19,20 e 21 da Lei $n^{\circ}$ 1.079/1950, interpretados conforme à Constituição, para que se entenda que as "diligências" e atividades ali previstas não se destinam a provar a improcedência da acusação, mas apenas a esclarecer a denúncia; e (2) para declarar não recepcionados pela $\mathrm{CF} / 88$ os artigos 22 , caput, $2^{\mathrm{a}}$ parte [que se inicia com a expressão "No caso contrário..."], e $\S \S 1^{\circ}, 2^{\circ}$, $3^{\circ}$ e $4^{\circ}$ da Lei $n^{\circ} 1.079 / 1950$, que determinam dilação probatória e segunda deliberação na Câmara dos Deputados, partindo do pressuposto que caberia a tal casa pronunciar-se sobre o mérito da acusação, vencidos os Ministros Edson Fachin (Relator), Dias Toffoli e Gilmar Mendes; quanto ao item D, por unanimidade, indeferiu o pedido, por reconhecer que a proporcionalidade na formação da comissão especial pode ser aferida em relação aos partidos e blocos partidários; quanto ao item $\mathbf{E}$, por maioria, deferiu integralmente o pedido, para estabelecer que a defesa tem o direito de se manifestar após a acusação, vencido o Ministro Marco Aurélio; quanto ao item F, por unanimidade, deferiu integralmente o pedido, para estabelecer que o interrogatório deve ser o ato final da instrução probatória; quanto ao item G, por maioria, deferiu parcialmente o pedido para dar interpretação conforme a Constituição ao art. 24 da Lei no 1.079/1950, a fim de declarar que, com o advento da $\mathrm{CF} / 88$, o recebimento da denúncia no processo de impeachment ocorre apenas após a decisão do Plenário do Senado Federal, vencidos, nessa parte, os Ministros Edson Fachin (Relator), Dias Toffoli e Gilmar Mendes, e declarar que a votação nominal deverá ser tomada por maioria simples e presente a maioria absoluta de seus membros, vencidos, nesse ponto, os Ministros Edson Fachin (Relator), Gilmar Mendes e Marco Aurélio; quanto ao item $\mathbf{H}$, por maioria, deferiu parcialmente o pedido para declarar constitucionalmente legítima a aplicação analógica dos arts. 44, 45, 46, 47, 48 e 49 da Lei $n^{\circ} 1.079 / 1950$ - os quais determinam o rito do processo de impeachment contra Ministros do Supremo Tribunal Federal e o Procurador-Geral da República - ao processamento no Senado Federal de crime de responsabilidade contra Presidente da República, vencidos os Ministros Edson Fachin (Relator), Dias Toffoli e Gilmar Mendes; quanto ao item I, por maioria, deferiu integralmente o pedido para declarar que não foram recepcionados pela $\mathrm{CF} / 88$ os arts. $23, \S \S 1^{\mathrm{o}}, 4^{\mathrm{o}}$ e $5^{\mathrm{o}} ; 80,1^{\mathrm{a}}$ parte; e 81 , todos da Lei $\mathrm{n}^{\mathrm{o}} 1.079 / 1950$, porque 


\begin{abstract}
estabelecem os papeis da Câmara e do Senado Federal de modo incompatível com os arts. 51, I; 52, I; e $86, \S 1^{\circ}$, II, da CF/88, vencidos, em menor extensão, os Ministros Edson Fachin (Relator), Dias Toffoli e Gilmar Mendes; quanto ao item $\mathbf{J}$, por unanimidade, indeferiu o pedido para afirmar que os senadores não precisam se apartar da função acusatória; quanto ao item $\mathbf{K}$, por unanimidade, indeferiu o pedido para reconhecer a impossibilidade de aplicação subsidiária das hipóteses de impedimento e suspeição do CPP relativamente ao Presidente da Câmara dos Deputados. Quanto à cautelar incidental (candidatura avulsa), por maioria, deferiu integralmente o pedido para declarar que não é possível a formação de comissão especial a partir de candidaturas avulsas, vencidos os Ministros Edson Fachin (Relator), Dias Toffoli, Gilmar Mendes e Celso de Mello. Quanto à cautelar incidental (forma de votação), por maioria, deferiu integralmente o pedido para reconhecer que a eleição da comissão especial somente pode se dar por voto aberto, vencidos os Ministros Edson Fachin (Relator), Teori Zavascki, Dias Toffoli, Gilmar Mendes e Celso de Mello. O Tribunal, por maioria, resolveu questão de ordem suscitada da tribuna para reafirmar o quorum de maioria simples para deliberação do Senado quanto ao juízo de instauração do processo, vencidos os Ministros Edson Fachin e Marco Aurélio, que estabeleciam o quorum de 2/3. Ausente, nesta deliberação, o Ministro Gilmar Mendes. Ao final, o Tribunal, por unanimidade, converteu o julgamento da medida cautelar em julgamento de mérito. Ausente, nesta questão, o Ministro Gilmar Mendes. Presidiu o julgamento o Ministro Ricardo Lewandowski. Plenário, 17.12.2015.
\end{abstract}

Por fim, vale a advertência de que o que se buscou nestas linhas, com estes exemplos de julgamento, foi apenas expor dois extremos no plano da fundamentação. Cabe ao leitor formular suas próprias conclusões. Todavia, por um imperativo metodológico vale oferecer considerações finais.

Por fim, vale a advertência de que o que se buscou nestas linhas, com estes exemplos de julgamento, foi apenas expor dois extremos no plano da fundamentação. Cabe ao leitor formular suas próprias conclusões. Todavia, por um imperativo metodológico vale oferecer considerações finais.

\title{
CONCLUSÃO
}

O exercício da jurisdição constitucional estabelecendo limite ao poder majoritário do legislador não pode ser justificado apenas com o argumento de se tratar de uma autoridade constitucionalmente conferida. É possível distinguir, na legitimidade da jurisdição constitucional, entre uma esfera externa e outra interna. A legitimação externa deriva ou da legitimidade implícita no momento fundador, que se materializa no processo constituinte, ou do processo continuado de diálogo e aperfeiçoamento entre os fundadores e as gerações seguintes, a partir do elemento de coesão e de integração que o processo democrático viabiliza. Mas requer um devido processo jurisdicional também.

A legitimação interna da jurisdição constitucional deriva sim, em parte, da atribuição constitucional de competência, mas depende em muito maior medida do respeito a um processo objetivo que amplie os sujeitos autorizados a oferecer argumentos 
que influenciem no julgamento - uma comunidade aberta de interpretes da constituição -. Nessa ordem de ideias as audiências públicas e figuras de intervenção como o amicus curiae são condição de legitimidade toda vez que o alcance da declaração da constitucionalidade ou da inconstitucionalidade transcender a esfera da administração pública alcançando a sociedade. Não se trata de uma escolha arbitrária do relator da causa, trata-se de uma exigência de credibilidade do exercício do poder de julgar. A intervenção de novos sujeitos e a interlocução com a sociedade não decorrem de uma necessidade dos magistrados de melhor se prepararem para o julgamento, atende a uma necessidade objetiva da decisão que se enriquece e se legitima com a participação de mais atores, como a apresentação de mais argumentos os quais, como foi sustentado, integram a fundamentação.

Ora, o STF julga com e sem efeito vinculante. Sem vincular o processo que prepara, possibilita e legitima o julgamento é um processo comum, inter partes $(\mathrm{CR}$, art. 102, I "b" até "o", "r" e II). A racionalidade exigível para justificar a decisão é própria dos discursos de aplicação, visa resolver a causa, sua motivação é persuasiva. Quando vincula (CR, art. 102, I "a", "p", “q", III e 103-A) exige-se uma racionalidade voltada para o entendimento, com motivação convincente, que incorpore os argumentos da sociedade que a provoca e com isso demonstra correção.

Não tem sido raro, especialmente no exame de ADPF o ingresso de amici curiae e a realização de audiências públicas, a prática, porém, parece estar associada ao objeto da demanda predominando quando o conteúdo diz respeito a temas morais; nestes casos a fundamentação é naturalmente enriquecida, porém, o que se defende é que essa técnica não deve sofrer limite, pois não responde a uma necessidade redutível aos temas que envolvem escolhas morais. No ambiente democrático o alcance e efeitos da decisão já reclamam, por si só, a abertura da fundamentação.

O propósito é pragmático e normativo, envolve como foi exposto, o objetivo de possibilitar a coordenação de interesses contrapostos na realidade social por meio da regulação de conflitos e da cooperação. Trata-se de cobrar um discurso de fundamentação de normas que atuam sobre a realidade o que supõe considerar as condições de aplicação das proposições expostas ao público. Além do mais, tanto argumentos pragmáticos quanto éticos, é bom que se diga, devem satisfazer a pretensão racional de universalidade que é própria dos argumentos morais. O agir comunicativo serve ao propósito legitimador operando como elemento de integração. Temos de inventar verdades práticas. Elas se encontram fora de nós, são extraídas do procedimento de argumentação que permite e obriga considerar o ponto de vista do outro, de cada um, das partes que provocam a jurisdição e do público que observa.

Democracia, entendida na ética do discurso como um arranjo social compatível com sociedades complexas como a brasileira, por ser um modelo político aberto e procedimental tem de inverter a equação de poder nas relações centro-periferia, tanto na ordem internacional, o que é fácil de ver, quanto na ordem interna, o que já não é tão evidente. Na vivência democrática as formas de comunicação surgidas no exercício da autonomia própria da esfera privada são direcionadas para o espaço público ativo. $\mathrm{O}$ poder comunicativo dos cidadãos (se e quando livres de manipulações e coerções o que implica igual oportunidade de fruição dos direitos fundamentais sociais) - partes dialeticamente contrapostas - tem de assediar, invadir e subordinar o poder burocrático da administração que inclui o poder jurisdicional. 


\section{REFERÊNCIAS BIBLIOGRÁFICAS}

ALEXY, Robert. Teoria da Argumentação Jurídica. São Paulo: Landy, 2001.

APEL, Karl-Otto. La ética del discurso como ética de la responsabilidad: una trasformación postmetafísica de la ética de Kant. No Ética del discurso. Ética de la liberación. Madrid: Editorial Trotta, 2005.

ARISTÓTELES. Retórica. Lisboa: Imprensa Nacional-Casa da Moeda, 2006.

BARROSO, Luis Roberto. Controle de Constitucionalidade no Direito Brasileiro. 3 ed. São Paulo: Saraiva, 2009.

BAUMAN, Zygmunt. O mal-estar da pós-modernidade. Rio de Janeiro: Zahar, 1998.

CARVALHO, José Murilo. A formação das Almas. O imaginário da República no Brasil. Rio de Janeiro: Cia das Letras, 17 $7^{\mathrm{a}}$ reimpressão, 2007.

CUNHA, Paulo Ferreira da. Retórica e Hermenêutica na origem do direito. Disponível em: <http://www.hottopos.com/videtur17/pfc_retdir.htm>. Acesso em: 20 mai. 2016.

GÜNTHER, Klaus. Teoria da Argumentação no Direito e na Moral: justificação e aplicação. São Paulo: Landy, 2004.

HABERMAS, Jürgen. Teoria de la acción comunicativa. Madrid: Editorial Trotta, 2010. Lógica das Ciências Sociais. Petrópolis: Vozes, 2009.

. Comentários à ética do discurso. Lisboa: Piaget editora, 1991.

HEGEL, G. F. H., A sociedade civil burguesa. Lisboa: Editorial Estampa, 1979.

LÉVINAS, Emmanuel. Humanismo do outro homem. Petrópolis: Vozes, 1993.

MASSAÚ, Guilherme Camargo. A possibilidade da diferença: o indivíduo e a pessoa e a sociedade e comunidade. Juris Poiesis, ano 12, n. 12, jan-dez 2009, p. 183-210.

MIRANDA, Francisco Pontes de. Comentários à Constituição de 1946, Tomo III, 3 ed. Rio de Janeiro: Borsoi, 1960.

SALDANHA, Nelson. O jardim e a praça. Rio de Janeiro: Atlântica Editora. 2005.

SARMENTO, Daniel. Por um constitucionalismo inclusivo. Rio de Janeiro: Lumen Juris, 2010.

STRECK, Lênio. Apresentação a obra Hermenêutica Constitucional. TRIBE, Laurence. e DORF, Michael. Belo Horizonte: Del Rey, 2007.

Recebido em: 25 de julho de 2016.

Aprovado em: 10 de agosto de 2016. 